\title{
Maitotilojen suorituskyky vuosina 1989 - 2000
}

Timo Sipiläinen

MTT Taloustutkimus, Luutnantintie 13,00410 Helsinki, Timo.Sipilainen@mtt.fi

\section{Johdanto}

Tilakoon kasvattaminen on nähty yhtenä keskeisenä keinona tuotannon kannattavuuden parantamiseksi, sillä siirryttäessä saman tuotantosuunnan tiloilla pienistä kokoluokista suuriin, kannattavuus yleensä paranee. Tilakoon kasvaessa yksikkökustannukset tyypillisesti alenevat - ainakin tiettyyn rajaan saakka (Riepponen 2003).

Tilakoon kasvaessa kuitenkin tuotantoprosessin hallinnan, tuotteiden markkinoinnin, panosten ostotoiminnan, rahoituksen ja henkilöstön johtamisen vaatimukset ja myös riskit kasvavat osin jopa ylisuhteisesti. Tutkimuksissa on pyritty selvittämään, jatkuuko yksikkökustannusten lasku vai kääntyvätkö ne jossain vaiheessa nousuun, kun tilakoko kasvaa riittävästi. Yksikkökustannusten nousun mahdollisuutta on perusteltu nimenomaan liikkeenjohtokykyyn liittyvillä puutteilla. Suurissa yrityksissä yksikkökustannukset voivat olla pieniä alemmat, koska rajallisesti jaettavissa olevien panosten kapasiteetti voidaan käyttää yhä täysimääräisemmin, tehtävissä voidaan erikoistua ja/tai voidaan saada määräalennuksia panoksista tai määrälisiä tuotteista. Jos liikkeenjohtokyky on kiinteä tekijä, muita, muuttuvia panoksia joudutaan käyttämään yhä enemmän tuotannon kasvaessa ja lopulta yksikkökustannukset saattavat kääntyä nousuun (Alvarez ja Arias 2003).

Tässä tutkimuksessa tarkasteltiin yrityskoon yhteyttä tehokkuuteen ja kannattavuuteen sekä niiden muutoksiin. Näin pyrittiin arvioimaan, miten suuria kokoedut ovat, mistä ne aiheutuvat ja miten ne ovat realisoituneet yritysten kasvun yhteydessä. Tämän lisäksi tarkasteltiin suurtuotannon etujen ilmenemistä ja niiden yhteyttä liikkeenjohtokykyyn.

\section{Aineisto ja menetelmät}

Tutkimuksessa käytettiin MTT Taloustutkimuksen kannattavuustutkimuksen ylläpitämää maatalouden kannattavuuskirjanpitoaineistoa vuosilta 1989 - 2000. Tutkimustilat olivat erikoistuneet maidontuotantoon. Tulokset raportoitiin erikseen sekä koko tilajoukolle että koko tarkasteluajanjakson kirjanpitotilana pysyneiden tilojen paneelille. Paneeliaineiston avulla voitiin tutkia ajan yli tapahtuneita muutoksia samoilla tiloilla.

Tehokkuutta ja tuottavuutta mitattiin DEA (data envelopment analysis) menetelmällä laskettujen indeksien avulla. Tutkimuksessa mitattiin niin kustannus-, allokatiivista kuin teknistäkin tehokkuutta. Nämä saavat arvon yksi, kun tuotanto on täysin tehokasta. Tuottavuuden muutosta ajan yli mitattiin eiparametrisen Malmquist-indeksin avulla, joka dekomponoitiin teknisen tehokkuuden muutokseen ja tekniseen muutokseen (Färe ym. 1994). Mallit laadittiin käyttäen tuotoksina joko pelkästään tilan maitotuotosta tai sekä maitotuotosta että muita nautayksiköitä kuin lehmiä. Panoksina käytettiin tilan työmenekkiä, peltoalaa, materiaaleja sekä kone- ja rakennuskustannusta.

Tutkimustilojen kannattavuus määritettiin perinteisen kannattavuuskertoimen (maatalousylijäämä jaettuna pääoman korkovaatimuksen ja viljelijäperheen palkkavaatimuksen summalla) avulla. Edellä mainittujen mittareiden muutokset kytkettiin tilakokoon ja sen muutoksiin.

\section{Tulokset ja tulosten tarkastelu}

\section{Kustannustehokkuus}

Maitotilojen keskimääräinen maitotuotos kasvoi lähes 50 prosentilla vuosina 1989 - 2000. Kustannustehokkuus vaihteli mallista riippuen $0,6-0,7$. Koko maitotila-aineistossa keskimääräinen kustannustehokkuus parani tutkimusperiodilla hiukan, mutta paneeliaineistossa se pysyi ennallaan tai laski jonkin verran. On kuitenkin huomattava, että tällöin verrattiin kunkin vuoden havaintoja ainoastaan saman vuoden havaintoihin, joten keskimääräiset yksikkökustannukset voivat nousta tai laskea vuosien välillä. Kunkin vuoden kes- 
kimääräinen kustannustehokkuus kertoo ainoastaan, kuinka lähellä kyseisen vuoden minimiyksikkökustannusta tilat toimivat.

Tilan maitotuotoksen ja kustannustehokkuuden Spearman järjestyskorrelaatio oli positiivinen ja tilastollisesti merkitsevä kaikkina vuosina. Korrelaatio oli alimmillaan 1990-luvun lopulla, jolloin tilakohtaisen maitotuotoksen kasvu oli nopeinta. Vaikka vakioskaalatuottojen mallin mukaan kustannustehottomimmat tilat olivat maitomäärältään yleensä ottaen pienimpiä, suurimmat tilat eivät välttämättä olleet kustannustehokkaimpia. Tilakohtainen vaihtelu oli myös varsin suurta. Kustannustehokkuuden ja tilakohtaisen maitotuotoksen keskinäinen yhteys vuonna 2000 esitetään kuvassa 1.

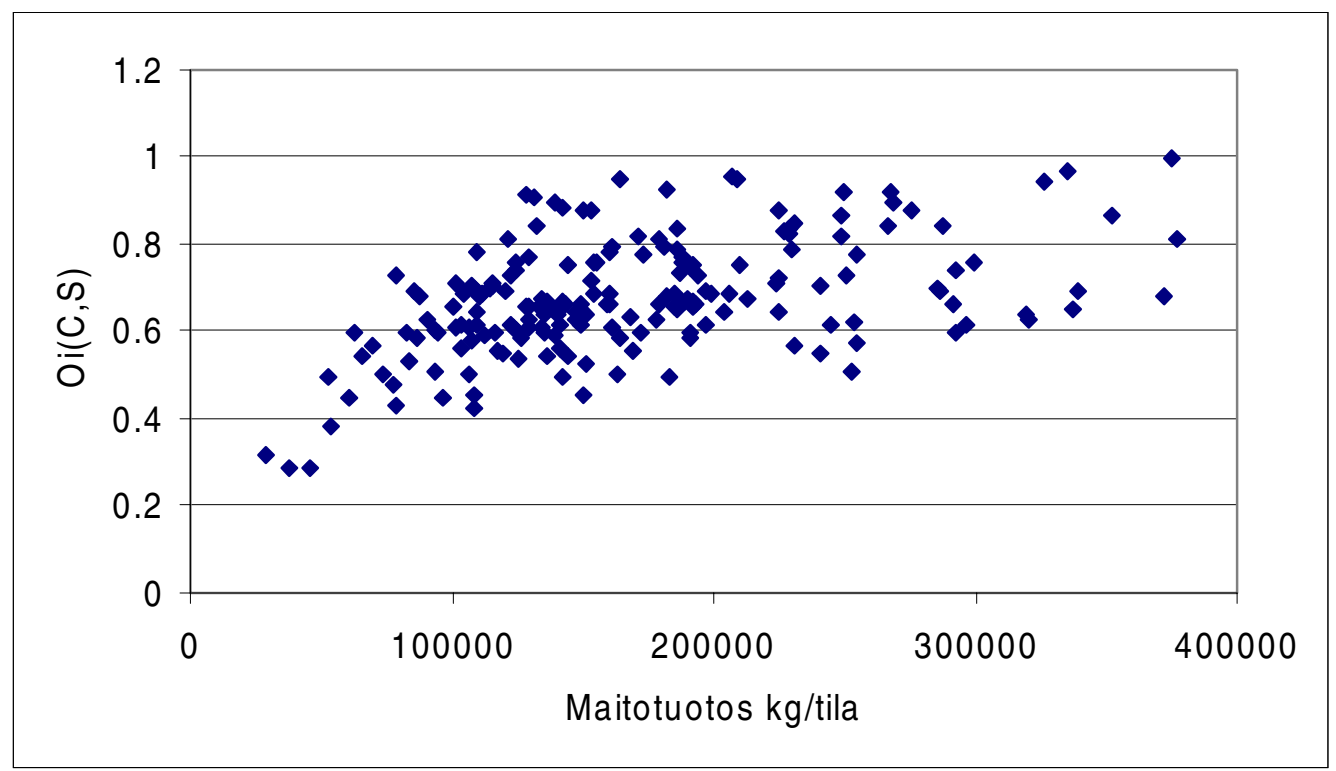

Kuva 1. Maitotuotos kg/tila ja kustannustehokkuus (Oi(C,S)) vuonna 2000.

Maitotilojen paneeliaineistossa kolmen vuoden liukuvia keskiarvoja käyttäen laskettu keskimääräinen kustannustehokkuus oli korkeampi kuin koko maitotila-aineistossa. Tämä aiheutui liukuvien keskiarvojen variaatiota vähentävästä vaikutuksesta sekä tilajoukon pienenemisestä. Tehottomuus jakautui lähes tasan teknisen tehottomuuden (radiaalisen etäisyyden tehokkaasta pinnasta) ja allokatiivisen tehottomuuden (kustannusten minimoinnin kannalta väärän panosten käyttösuhteen) kesken.

Maitotuotoksen suhteellisen tai absoluuttisen lisäyksen ja kustannustehokkuuden muutoksen välillä ei ollut selkeää yhteyttä. Nopeimmin kasvaneet maitotilat sijoittuivat tarkastelujakson alussa yleensä kustannustehokkuudeltaan keskitasoisten tilojen joukkoon.

\section{Tuottavuus}

Koko maitotila-aineistossa tuottavuuden kasvu oli mallista riippuen $0,77-1,49$ prosenttia vuodessa koko tutkimusperiodilla. Vuosien 1989 ja 2000 poispudottaminen laski tuottavuuskehityksen lähes nollaan. Tuottavuuden muutos aiheutui pääasiassa teknisestä muutoksesta, sillä tekninen tehokkuus ei juuri muuttunut.

Kolmen vuoden liukuvien keskiarvojen käyttö tuottavuuskehityksen tarkastelussa vähensi tuottavuuden ja sen osatekijöiden vuotuista vaihtelua. Paneelitiloilla Malmquist-tuottavuusindeksin keskiarvo vaihteli 1,7 prosentin vuotuisen nousun ja 0,3 prosentin vuotuisen laskun välillä näinä periodeina (taulukko 1). Kokonaistuottavuuden muutos jäi näin laskien keskimäärin 0,8 prosenttiin. Tuottavuuden muutos oli positiivinen ensimmäisiä vuosia lukuun ottamatta. Tilojen välinen hajonta oli suuri, sillä suurimmillaan tuottavuuden lasku oli yli kolme prosenttia vuodessa, kun taas vastaava nousu oli suurimmillaan yli seitsemän prosenttia. Tekninen muutos oli positiivinen (tuotantorintaman siirtymä) ollen keskimäärin yhden prosentin vuodessa. Skaalatehokkuuden muutos oli keskiarvoltaan lähes nolla. Skaalatehokkuuden muutoksissa ei ollut systemaattista eroa ennen EU-jäsenyyttä ja EU:in liittymisen jälkeen. Puhdas tekninen tehokkuus aleni keskimäärin hieman. 
Taulukko 1. Paneelimaitotilojen tuottavuuden muutoksen (M) geometriset keskiarvot jaoteltuna tekniseen muutokseen (TC) ja teknisen tehokkuuden muutokseen (TEC), joka jaotellaan edelleen skaalatehokkuuden muutokseen (SEC) $)^{\mathrm{a}}$ ja puhtaaseen teknisen tehokkuuden muutokseen (PEC).

\begin{tabular}{llrrrr}
\hline & $\mathrm{M}$ & $\mathrm{TC}$ & \multicolumn{1}{l}{ TEC } & \multicolumn{1}{c}{ SEC } & \multicolumn{1}{c}{ PEC } \\
\hline $1990-91$ & $-0,26 \%$ & $1,08 \%$ & $-1,32 \%$ & $-1,35 \%$ & $0,03 \%$ \\
$1991-92$ & $0,62 \%$ & $0,78 \%$ & $-0,16 \%$ & $0,42 \%$ & $-0,57 \%$ \\
$1992-93$ & $1,02 \%$ & $1,69 \%$ & $-0,66 \%$ & $-0,42 \%$ & $-0,24 \%$ \\
$1993-94$ & $0,14 \%$ & $-1,81 \%$ & $2,00 \%$ & $1,22 \%$ & $0,77 \%$ \\
$1994-95$ & $0,35 \%$ & $1,01 \%$ & $-0,65 \%$ & $-0,68 \%$ & $0,03 \%$ \\
$1995-96$ & $1,62 \%$ & $1,89 \%$ & $-0,26 \%$ & $-1,12 \%$ & $0,87 \%$ \\
$1996-97$ & $1,68 \%$ & $1,87 \%$ & $-0,19 \%$ & $1,69 \%$ & $-1,85 \%$ \\
$1997-98$ & $0,40 \%$ & $0,22 \%$ & $0,18 \%$ & $1,28 \%$ & $-1,09 \%$ \\
$1998-99$ & $1,13 \%$ & $1,87 \%$ & $-0,73 \%$ & $-0,94 \%$ & $-0,23 \%$ \\
\hline $1990-99$ & & & & & \\
Keskiarvo & $0,80 \%$ & $0,97 \%$ & $-0,17 \%$ & $0,11 \%$ & $-0,24 \%$ \\
Minimi & $-3,38 \%$ & $-2,36 \%$ & $-4,12 \%$ & $-2,22 \%$ & $-4,27 \%$ \\
Maksimi & $7,43 \%$ & $4,38 \%$ & $6,81 \%$ & $4,06 \%$ & $4,93 \%$ \\
\hline
\end{tabular}

${ }^{a}$ Panosorientoitunut skaalatehokkuus.

\section{Kannattavuus}

Kannattavuus ja kustannustehokkuus korreloivat erittäin merkitsevästi keskenään. Kannattavuuden ja kustannustehokkuuden keskinäisessä yhteydessä ei ollut havaittavissa systemaattista muutosta ennen ja jälkeen EU-jäsenyyden, vaikka tukien merkitys tulonmuodostuksessa kasvoi EU-jäsenyyden myötä samalla kun tuotantotoiminnasta saatavan tulon osuus pieneni.

Kannattavuuskerroin korreloi tilan maitotuotoksen kanssa positiivisesti, joten suurilla tiloilla kannattavuus oli pieniä tiloja parempi. Lähes puolet tarkastelujaksolla maitomääräänsä kasvattaneista tiloista ei kuitenkaan ollut onnistunut parantamaan kannattavuuttaan. Toisaalta muutamat maitomääräänsä voimakkaasti kasvattaneet tilat olivat onnistuneet parantamaan kannattavuuttaan oleellisesti (kuva 2).

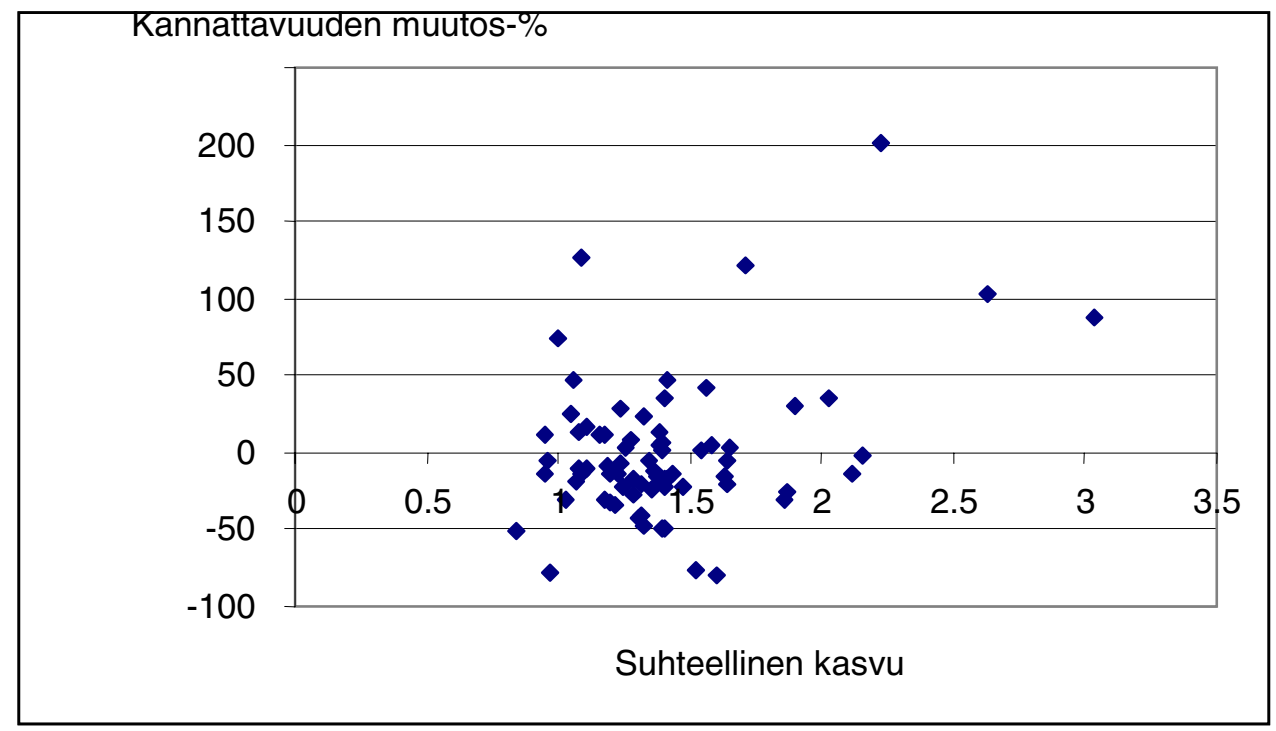

Kuva 2. Tilan maitomäärän suhteellisen kasvun ja kannattavuuden suhteellisen muutoksen yhteys.

Tarkasteluajanjakson alun ja lopun tehokkuudet ja kannattavuudet korreloivat tilastollisesti merkitsevästi (r $>0,500$ ) keskenään osoittaen näiden mittareiden huomattavaa pysyvyyttä tilatasolla. Yksittäistapauksissa varsin suuret muutokset olivat mahdollisia. Toisaalta keskimääräinen tehokkuus on pysynyt samalla tasolla koko tarkasteluajanjakson ajan, joten tilakohtaiset erot eivät keskimäärin ole juurikaan supistuneet. 


\section{Suurtuotannon edut ja liikkeenjohtokyky}

Suurtuotannon etujen toteutumista ja liikkeenjohtokykyä tarkasteltiin erillisenä analyysina vuosien 1998 2000 aineistossa. Analyysin mukaan yksikkökustannukset alenivat yrityskoon kasvaessa, mutta hidastuen. Kustannusten jousto yrityskoon (tuotosmäärän) suhteen oli maitotiloilla keskimäärin -0,18. Siten suurtuotannon edut vallitsevat keskimäärin ja myös valtaosassa havaintopisteitä. Teknistä tehokkuutta indikaattorina käyttäen mitatun liikkeenjohtokyvyn paranemisella oli niin ikään yksikkökustannuksia alentava vaikutus. Maitotiloilla yksikkökustannus aleni keskiarvopisteessä 0,11 prosenttia liikkeenjohtokyvyn parantuessa prosentilla.

Yrityskoon ja liikkeenjohtokyvyn välillä ei havaittu riippuvuutta, joka olisi vaikuttanut suurtuotannon etujen realisoitumiseen. Tältä osin tulos poikkesi Alvarezin ja Ariasin (2003) esittämistä tuloksista espanjalaisilta maitotiloilta. Kuitenkin samallakin liikkeenjohtokyvyn tasolla tilalla pitäisi olla mahdollista päästä alempiin yksikkökustannuksiin suurtuotannon etuja hyödyntäen.

Hyvien mittareiden löytäminen liikkeenjohtokyvylle on ongelmallista. Edellä mainitussa tutkimusosiossa liikkeenjohtokykyä mitattiin teknisen tehokkuuden avulla. Ongelmana on, että mittari sisältää liikkeenjohdon erojen lisäksi myös ne tilakohtaiset erot, joihin viljelijä itse ei voi juurikaan vaikuttaa (maan laatu, mikroilmasto jne.). Osin tästä syystä regressioanalyysissa liikkeenjohtokyvyn mittarina käytettiin varsinaisen tehokkuusluvun asemasta tehokkuuden järjestyslukua.

\section{Johtopäätökset}

Yksikkökustannukset alenevat siirryttäessä pienistä tiloista suuriin mutta hidastuen. Tutkimusaineiston puitteissa ei kuitenkaan voitu luotettavasti määrittää, millaiseen yrityskokoon saakka yksikkökustannukset alenevat. Liikkeenjohtokyky vaikuttaa niin ikään yksikkökustannuksiin, mutta sen yhteyttä suurtuotannon etujen tekniseen toteutumiseen ei voitu osoittaa.

Tehokkuus- ja kannattavuusmittarit korreloivat yleensä positiivisesti tilakoon kanssa. Tästä huolimatta tilakoon muutokset ja muutokset tehokkuudessa ja kannattavuudessa eivät olleet selkeästi kytköksissä toisiinsa. Useat maitotilat ovat kasvattaneet kokoaan vasta EU-jäsenyyden aikana. Tämän vuoksi on mahdollista, että tehokkuuden ja kannattavuuden muutokset kytkeytyvät kasvun ajoitukseen. Tutkimuksissa on todettu, että kannattavuus ja maksuvalmius eivät välttämättä parane välittömästi kasvun tapahduttua (Pyykkönen 1996). Kasvanut tilakoko antaa kuitenkin mahdollisuuden kannattavuuden parantamiseen, mutta tuloksen paraneminen ei seuraa kasvusta automaattisesti ja välittömästi. Toisaalta myös jotkin tilat, jotka ovat kasvaneet vain vähän tai eivät ole kasvaneet juuri lainkaan, ovat onnistuneet parantamaan tehokkuuttaan ja kannattavuuttaan merkittävästi.

Liikkeenjohtokyky on muutoksissa keskeisessä asemassa. Liikkeenjohtokyvyn mittaaminen on kuitenkin ongelmallista. Jos liikkeenjohtokyvyn mittarina käytetään jotakin tuotannon taloudellista tai teknistä tulosmuuttujaa, siihen kytkeytyvät aina myös tilakohtaiset, yrittäjästä riippumattomat tekijät. Tilakohtaisista tekijöistä ei saada tietoa tutkimatta tiloja tarkemmin esimerkiksi tapaustutkimuksen keinoin. On ilmeistä, että tilastollisen päättelyn ja joidenkin tapausten tarkemman tutkimisen yhdistäminen voisi olennaisesti lisätä analyysin syvyyttä.

\section{Kirjallisuus}

Alvarez, A. \& Arias, C. 2003. Diseconomies of size with fixed managerial ability. American Journal of Agricultural Economics. 85(1):134-142.

Färe, R., Grosskopf, S. \& Lovell, C.A.K. 1994. Production frontiers. Cambridge University Press. ISBN 0521-42033-4 (hardback)

Pyykkönen, P. 1996. Maatalouden kasvuprosessi. Empiirinen tutkimus maatalouden rakennekehityksestä ja tilojen talouden kehityksestä. Pellervon taloudellinen tutkimuslaitos. Raportteja ja artikkeleita. N:o 141.

Riepponen, L. 2003. Maidon ja viljan tuotantokustannukset Suomen kirjanpitotiloilla vuosina 1998-2000. Maaja elintarviketalous 19. MTT. ISBN 951-729-735-1

Sipiläinen, T. 2003. Suurten maito- ja viljatilojen suorituskyky ja sen kehittäminen. Helsingin ylipisto. Taloustieteen laitos. Julkaisuja nro 38. ISBN 952-10-1425-3 